\title{
HUBUNGAN PENGETAHUAN DAN PRILAKU REMAJA PUTRI DENGAN KEJADIAN KEPUTIHAN DI KELAS XII SMA NEGERI I SEUNUDDON KABUPATEN ACEH UTARA TAHUN 2012
}

\author{
Anggun Kurnia Dewi \\ STIKes Surya Mitra Husada Kediri \\ kurniaanggun08@gmail.com
}

\begin{abstract}
Abstrak
Kesehatan reproduksi menurut WHO adalah suatu keadaan fisik, mental dan sosial yang utuh, bukan hanya bebas dari penyakit atau kecacatan dalam segala aspek yang berhubungan dengan sistem reproduksi, fungsi serta prosesnya. Atau suatu keadaan dimana manusia dapat menikmati kehidupan seksualnya serta mampu menjalankan fungsi dan proses reproduksinya secara sehat dan aman. Tujuan penelitian untuk mengetahui hubungan pengetahuan, prilaku dengan kejadian keputihan di kelas 2 SMA Negeri I Seunuddon Kabupaten Aceh Utara. Terdapat hubungan pengetahuan, prilaku, terhadap kejadian keputihan. Pengetahuan remaja terhadap pencegahan keputihan akan memberi pemahaman tentang kondisi dan perubahan tubuh pada saat keputihan sehingga tidak terjadi salah pengertian dan kecemasan yang berlebihan terhadap kondisi tersebut. Jika siswa ingin terhindar dari keputihan, maka remaja putri mesti menjaga kebersihan daerah kewanitaan dan harus membiasakan perilaku yang baik.
\end{abstract}

\section{Kata kunci : Keputihan, Pengetahuan, Prilaku}

\section{Latar Belakang}

Kesehatan reproduksi menurut WHO adalah suatu keadaan fisik, mental dan sosial yang utuh, bukan hanya bebas dari penyakit atau kecacatan dalam segala aspek yang berhubungan dengan sistem reproduksi, fungsi serta prosesnya. Atau suatu keadaan dimana manusia dapat menikmati kehidupan seksualnya serta mampu menjalankan fungsi dan proses reproduksinya secara sehat dan aman (Boyke, 2008). Organ intim wanita, seperti vagina sangat sensitif dengan kondisi lingkungan. Karena letaknya tersembunyi dan tertutup, vagina memerlukan suasana kering. Kondisi lembab akan mengundang berkembang biaknya jamur dan patogen. Ini adalah salah satu penyebab keputihan 
(Widyastuti, 2009). Keputihan atau floour albus merupakan masalah yang cukup serius dialami wanita, keputihan tidak menyebabkan kanker, namun salah satu gejala kanker mulut rahim, bisa juga terjadi pada mereka yang belum pernah melakukan hubungan seksual jika wanita itu sering merokok. Wanita yang merokok memiliki kecanduan 12 kali lebih banyak dibandingkan wanita yang tidak merokok untuk menderita penyakit kanker mulut rahim. Keputihan ada yang normal dan ada yang tidak normal. Dalam keadaan normal, vagina akan menghasilkan cairan yang berwarna putih, tidak berbau dan dalam jumlah yang tidak berlebihan, cairan ini tidak berperan sebagai sesuatu sistem perlindungan dimana keputihan dapat mengurangkan gesekan antara dinding vagina ketika berjalan maupun ketika melakukan hubungan seksual. Wanita tidak seharusnya bimbang dengan masalah ini, keputihan yang normal berlaku beberapa hari sebelum datang haid, peningkatan libido ketika hamil atau selepas Menopause (Boyke, 2008). Menurut (WHO, 2010) bahwa sekitar $75 \%$ perempuan di dunia pasti akan mengalami keputihan paling tidak sekali seumur hidup nya, dan sebanyak $45 \%$ akan mengalami dua kali atau lebih, sedangkan wanita Eropa yang mengalami keputihan sebesar 25\%. Di Indonesia sebanyak $75 \%$ wanita pernah mengalami keputihan minimal satu kali dalam hidupnya dan $45 \%$ di antaranya mengalami keputihan sebanyak dua kali atau lebih. Kondisi seperti ini bisa dicegah dengan melakukan kebiasaan vulva hygiene yang baik, sedangkan kebiasaan ini sendiri merupakan perilaku yang harus dibiasakan oleh setiap individu dan disertai dengan pengetahuan, untuk itu tenaga kesehatan mempunyai peranan penting untuk mendidik masyarakat tentang pentingnya hygiene yang baik untuk mencegah keputihan melalui penyuluhan.

\section{Kasus/Masalah}

Berdasarkan data statistik Indonesia tahun 2008 dari 43,3 juta jiwa remaja berusia 15-24 tahun berperilaku tidak sehat, ini merupakan salah satu penyebab dari keputihan (Maghfiroh, 2010). Berdasarkan data statistik provinsi Aceh tahun 2011 jumlah remaja putri yaitu 2,9 juta jiwa berusia 15-24 tahun, diantaranya $45 \%$ pernah mengalami keputihan. Data RSUD CM Lhokseumawe tahun 2011 menyebutkan bahwa jumlah penderita kanker mulut rahim (servik) adalah 54 jiwa. Penderita yang sakit dalam keadaan stadium lanjut, kanker mulut rahim ini diawali dengan keputihan yang lama yang tidak diobati (Dinkes, 2010). Berdasarkan data pra survei yang peneliti lakukan pada tanggal 13 Februari 2011 di SMA Negeri 1 Seunuddon dengan wawancarai pada 10 remaja putri, terdapat 7 remaja putri yang mengalami keputihan, setelah ditanyakan tentang vulva hygiene, maka 4 orang (40\%) selalu menjaga vulva hygiene, dan 3 orang (30\%) yang membersihkan vagina dengan sabun sirih dan 3 orang (30\%) lainnya tidak pernah menjaga vulva hygiene dengan baik. Tingkat pengetahuan remaja berpengaruh terhadap 
prilaku remaja dalam mencegah terjadinya keputihan, di SMA Negeri 1 Seunuddon remaja yang mengetahui tentang keputihan yaitu 4 orang (40\%), sementara sebanyak 6 orang $(60 \%)$ tidak mengetahui dengan jelas tentang masalah keputihan. Setelah di lakukan wawancara lebih lanjut ternyata sebagian besar remaja yaitu 5 orang dari 7 orang yang mengalami keputihan tersebut, memiliki pengetahuan yang terjadi terhadap masalah keputihan.

\section{Tinjauan Pustaka}

Keputihan adalah gejala penyakit yang ditandai oleh keluarnya cairan dari organ reproduksi dan bukan berupa darah. Keputihan yang berbahaya adalah keputihan yang tidak normal (Blankast, 2008).

Klasifikasi keputihan, ada dua jenis keputihan yaitu :

1. Keputihan tidak normal (patologis)

2. Keputihan normal (fisiologis)

Perbedaan keputihan fisiologis dan yang patologis. Keputihan fisiologis terdiri atas cairan yang kadang- kadang berupa mukus yang mengandung banyak epitel dengan leukosit yang jarang, sedang pada keputihan patologis terdapat banyak leukosit (Sarwono, 2005).

Keputihan normal mempunyai ciri - ciri :

1. Cairan yang keluar encer

2. Berwarna bening atau krem

3. Tidak berbau

4. Tidak gatal

5. Jumlahnya sedikit
Disebut keputihan tidak normal jika mempunyai ciri-ciri sebagai berikut :

1. Cairan yang keluar bersifat kental

2. Berwarna putih susu, kuning atau hijau

3. Terasa gatal

4. Berbau tidak sedap

5. Menyisakan bercak pada pakaian dalam

6. Jumlahnya banyak

Faktor penyebab keputihan :

a. Infeksi vagina oleh jamur (candida albicans) atau parasit (tricomonas). Jenis infeksi yang terjadi pada vagina yakni, bacterial vaginosis, trikomonas, dan kandidiasis. Bakterial vaginosis merupakan gangguan vagina yang sering terjadi ditandai dengan keputihan dan bau tak sedap. Hal ini di sebabkan oleh lactobacillus menurun, bakteri patogen (penyebab infeksi) meningkat, dan $\mathrm{pH}$ vagina meningkat.

b. Faktor hygiene yang jelek

Kebersihan daerah vagina yang jelek dapat menyebabkan timbulnya keputihan. Hal ini terjadi karena kelembaban vagina yang meningkat sehingga bakteri patogen penyebab infeksi mudah menyebar.

c. Pemakaian obat-obatan (antibiotik, kortikosteroid, dan pil KB) dalam waktu lama. Karena pemakaian obat- obatan khususnya antibiotik yang terlalu lama dapat menimbulkan sistem imunitas dalam tubuh. Sedangkan penggunaan KB mempengaruhi keseimbangan hormonal wanita. Biasanya pada wanita yang 
mengkonsumsi antibiotik timbul keputihan.

d. Stres

Otak mempengaruhi kerja semua organ tubuh, jadi jika reseptor otak mengalami stress maka hormonal di dalam tubuh mengalami perubahan keseimbangan dan dapat menyebabkan timbulnya keputihan.

e. Penyebab lain keputihan adalah alergi akibat benda-benda yang dimasukkan secara sengaja atau tidak sengaja ke dalam vagina, seperti tampon, obat atau alat kontrasepsi, rambut kemaluan, benang yang berasal dari selimut, celana dan lainnya. Bisa juga karena luka seperti tusukan, benturan, tekanan atau iritasi yang berlangsung lama.

Cara mengatasi keputihan

a. Tanpa Obat

1. Menjaga agar daerah genetalia senantiasa bersih serta memperhatikan sabun yang di gunakan sebaiknya sabun yang tidak berparfum.

2. Hindari mandi dengan berendam

3. Menggunakan celana dalam dari bahan katun, tidak menggunakan celana dalam yang ketat.

4. Menghindari beraktivitas yang terlalu lelah, panas dan keringat yang berlebih.

5. Liburan untuk mengurangi stres karena stres merupakan suatu faktor timbulnya keputihan.

b. Dengan obat
1. Konsultasi dengan dokter karena dokter akan memberikan obat-obatan sesuai dengan jenis keputihan yang dialami.

2. Untuk keputihan normal tidak perlu dilakukan terapi khusus. Yang penting, bagaimana membersihkan organ intim secara benar dan teratur. Umumnya, cukup dengan sabun khusus vagina dan air bersih serta menjaga agar pakaian dalam tetap kering dan bersih.

3. Sedangkan keputihan yang tidak normal harus segera mendapatkan pengobatan media.

4. Keputihan yang dialami wanita hamil akibat infeksi bakteri diberikan obat dalam bentuk kapsul atau tablet yang aman dikonsumsi. Pada infeksi niceriagonorrhoeae, ada obat dalam bentuk kapsul yang dapat diminum. Sebaiknya, segera periksakan kandungan jika terjadi keputihan.

5. Pemeriksaan dilakukan dengan menggunakan alat khusus untuk mendapatkan gambaran alat kelamin secara lebih baik, seperti melakukan kolpokopi yang berupa optik untuk memperbesar gambaran leher rahim, liang senggama, dan bibir kemaluan.

6. Selain pengobatan medis, biasanya orang akan menggunakan daun sirih untuk mengurangi keputihan. Caranya, dengan meminum air daun sirih yang telah direbus terlebih dahulu. Cara ini 
cukup aman bagi ibu hamil dan bayinya (Suryana, 2009).

7. Dan yang terpenting bila suatu keputihan yang tidak sembuh dengan pengobatan biasa (antibiotika dan anti jamur) harus dipikirkan keputihan tersebut disebabkan oleh suatu penyakit keganasan seperti kanker leher rahim. Ini biasanya ditandai dengan cairan banyak, bau busuk, sering disertai darah tak segar. (Blankast, 2008 )

\section{Pembahasan}

a. Hubungan Pengetahuan Terhadap

Kejadian Keputihan Pada Remaja

Putri.

Pengetahuan remaja sangat berpengaruh dengan kejadian keputihan, pengetahuan remaja terhadap pencegahan keputihan akan memberi pemahaman tentang kondisi dan perubahan tubuh pada saat keputihan sehingga tidak terjadi salah pengertian dan kecemasan yang berlebihan terhadap kondisi tersebut.

Menurut Tanuwidjaya (2002), tingkat pengetahuan remaja berpengaruh terhadap kesehatannya yang dimiliki oleh remaja jika terjadinya kelainan atau gangguan kesehatan pada remaja, maka dapat segera diatasi secepat mungkin. Jadi, tingkat pengetahuan sangatlah erat kaitannya. Berdasarkan uraian diatas peneliti berasumsi bahwa pemahaman siswa terhadap kejadian keputihan serta informasi yang didapatkan akan sangat mempengaruhi pengetahuan siswa. Karena semakin banyak ibu siswa mendapatkan informasi tentang kejadian keputihan maka semakin baik juga pengetahuan siswa, sebaliknya semakin ibu tidak memperoleh informasi maka semakin kurang pula pengetahuan siswa tentang kejadian keputihan. Oleh karena itu pencegahan dan cara mengatasi keputihan sangatlah berpengaruh pada sikap prilaku bagaimana mereka mencegah dan mengatasi keputihan. Hal ini banyak remaja yang menyepelekan bahkan banyak juga yang tidak peduli akan kebersihan alat genetalia, karena banyak remaja yang kurang memehami dan masih kurangnya infomasi tentang kejadian keputihan.

b. Hubungan Perilaku Tehadap Kejadian Keputihan Pada Remaja Putri.

Prilaku remaja berpengaruh dengan keputihan. Prilaku yang baik dalam kehidupan sehari - hari sangat berpengaruh terhadap kejadian keputihan. Notoatmodjo (2003), mengungkapkan bahwa sebelum orang mengadopsi perilaku baru, namun demikian dari penelitian selanjutnya Rogers menyimpulkan 
bahwa perubahan perilaku tidak selalu melewati tahap-tahap tersebut di atas. Apabila penerimaan perilaku baru atau adopsi perilaku melalui proses seperti ini, di mana didasari oleh pengetahuan, kesadaran dan sikap yang positif, maka perilaku tersebut akan bersifat langgeng (long lasting). Sebaliknya apabila perilaku tersebut tidak didasari oleh pengetahuan dan kesadaran tidak berlangsung lama. Berdasarkan uraian diatas peneliti berasumsi bahwa, jika ibu mempunyai pengetahuan yang baik, pendidikan yang tinggi dengan perilaku yang positif, maka keadaan dan kondisi siswa tidak perlu dikhawatirkan, karena siswa berada pada keaadaan yang sehat setiap hari. Sedangkan jika siswa ingin terhindar dari keputihan, maka remaja putri mesti menjaga kebersihan daerah tersebut itu. Kebersihan organ kewanitaan hendaknya sejak bangun tidur dan mandi pagi, terutama remaja putri harus membiasakan perilaku yang baik.

\section{Kesimpulan}

Ada hubungan pengetahuan terhadap kejadian keputihan pada remaja putri di SMA Negeri I Seunuddon Kabupaten Aceh Utara Tahun 2012. Pengetahuan remaja terhadap pencegahan keputihan akan memberi pemahaman tentang kondisi dan perubahan tubuh pada saat keputihan sehingga tidak terjadi salah pengertian dan kecemasan yang berlebihan terhadap kondisi tersebut.

Ada hubungan perilaku tehadap kejadian keputihan pada remaja putri di SMA Negeri I Seunuddon Kabupaten Aceh Utara Tahun 2012. Jika siswa ingin terhindar dari keputihan, maka remaja putri mesti menjaga kebersihan daerah kewanitaan. Membersihkan organ kewanitaan hendaknya sejak bangun tidur dan mandi pagi, terutama remaja putri harus membiasakan perilaku yang baik. 


\section{Daftar Pustaka}

Blankast, Ariev. (2008). Mengatasi

Keputihan dengan Herbal,

http://gealgeol.com/2008/08/27/agar

keputihan-tak-berulang.html. di akses

20 Mei 2009

Boyke, (2008). Tanda Dan Gejala

KankerMulutRahim.http://www.pdpers i.co.id. (diakses tanggal 05 januari 2012).

Magfiroh,. (2010). KTI Hubungan Pengetahuan Dan Sikap Remaja Putri Terhadap Kejadian Flour ALbus Di SMA II jepara.

Prawirohardjo, Sarwono. (2005). Ilmu Kandungan, Jakarta, Yayasan Bina Pustaka Sarwono Prawirohardjo.

Widyastuti, (2009). Kesehatan Reproduksi. Fitramaya.Yogyakarta

Wiknjasastro, (1999). Pengertian

Keputihan. Dikutip Tanggal 20 April 2012. http//www.keputihan.com. 